\title{
圧縮靱性を持つ既製コンクリー UNIAXIAL COMPRESSIVE TEST 卜杭の一軸圧縮実験 FOR COMPRESSIVE DUCTILITY OF PRECAST CONCRETE PILE
}

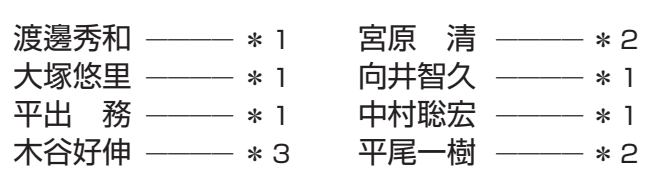

キーワード :

既製コンクリート杭，圧縮勒性，一軸圧縮試験，アンボンド鋼管， 拘束効果

Keywords:

Precast concrete pile, Compressive ductility, Uniaxial compressive test, Unbonded steel pipe, Confined effect

\section{1. はじめに}

2011 年東日本大震災や 2016 年熊本地震では, 構造設計時に十分な 検討が明示的に求められていない部位の損傷が顕在化し, その結果, 当該建築物が地震後, 継続使用できなくなる事例が確認されている 1)2)。上記の典型的被害の一つとして杭基礎の被害が挙げられる ${ }^{1) 2) 。 ~}$ 現行基準において杭基礎は中小地震における損傷制御を目的とした 設計が行われているものの, 大地震後の継続使用性を確保するため の基礎構造の終局限界状態における構造性能に基づく設計はほとん ど行われていない。一方で研究レベルでは, 大地震後の継続使用性を 確保するための設計法についての検討例が示された ${ }^{3) 4}$ が，この検討 例では場所打ちコンクリート杭を採用しており既製杭は採用されて いない。一般的に高強度コンクリートを用いた既製杭のような脆性 的に破壊する杭ではヒンジを許容できないために強度型の設計とな る。しかし, 大地震レベルの外力が作用する場合では強度型の杭では 断面が大きくなりすぎることから，勒性のある場所打ちコンクリー 卜杭が採用されている。このように, 大地震後の継続使用性を確保す るための設計においては, 勒性のある杭が必要とされている。

一方で, 杭基礎構造の構造性能については, 大地震時に対する杭基 礎構造を対象とした構造性能評価に資する技術資料が縓められつつ ある ${ }^{5)}$ 。そこでは, 場所打ち鋼管コンクリート杭や SC 杭では鋼管の 座屈によって終局状態に至ることが報告されており, 杭体の勒性能 を十分に確保するためには技術的な課題がある。

そこで本研究では, 上記の研究背景を踏まえ, 大地震時の変動軸力 作用下においても，建物の継続使用性を確保するために十分な勒性 能を有する杭体の開発を行う。今回は特に圧縮勒性に着目し, 基本的 な杭の圧縮挙動を確認することを目的に一軸圧縮実験を実施する。

\section{2. 実験概要}

\section{1 試験体概要}

試験体一覧を表 1 , 材料試験結果を表 2 と表 3 に, 代表的な試験体

Hidekazu WATANABE $-* 1$
Yuuri OHTSUKA — $* 1$
Tsutomu HIRADE- $* 1$
Yoshinobu KIYA_- $* 3$

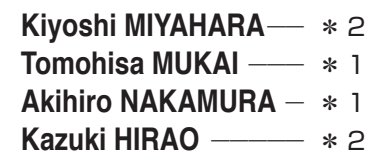

In order to develop precast concrete pile which has compressive ductility, static uniaxial compressive test was conducted using precast concrete pile specimens. Some of the specimens are precast concrete solid pile with unbonded steel pipe. In the result, precast concrete solid pile with unbonded steel pipe had ductile behavior, ultimate strain of specimens was more than $4.0 \%$. Furthermore, compressive capacities of the specimens are evaluated using existing formulae. In the result, the existing formulae underestimated the compressive capacities of test results.

の配筋図を図 1 に示す。A-3 を除いて, 外径 $400 \mathrm{~mm}$ 高さ $400 \mathrm{~mm}$ の既製 杭である。A シリーズは, 基本的な圧縮鞋性能を確認するための基礎 的な試験体である。中空円形断面を持つ既製コンクリート杭 A-1, 文 献 6)や 7) を参考に A-1 の外側にアンボンド鋼管を取り付けた A-2, 比較用として上部構造の圧縮勒性のある $\mathrm{RC}$ 柱を模した $\mathrm{A}-3$ の 3 体で ある。なお,ここでいうアンボンド鋼管とは, 試験体の上下の鋼製端 板と鋼管の接続をせず空隙を設けた鋼管のことである。既往の実験 ${ }^{6)}$ 7) と違い，施工性を考慮し鋼管とコンクリートの間の付着を除去する ような特別な処理はしていないが，上下に設けたそれぞれ $10 \mathrm{~mm} の$ 空 隙を設けることでアンボンド鋼管に直接圧縮力が伝達しないように 設計した。一方，B シリーズは中空断面での圧縮勒性を発揮する杭が 難しいことを想定し，断面を中実断面に変更した杭試験体を用いた 検討を実施した。B シリーズは既製コンクリート杭を想定したため, 気中にて打設し, 試験体端部に端板を設置した。B-1 試験体は中実断 面を持つ無筋の既製コンクリート杭であり, B-1 試験体の外側にアン ボンド鋼管を取り付けたものが B-2 シリーズであり, 本論文ではこ れをアンボンド鋼管巻き中実杭とよぶ。B-2 シリーズでは, アンボン ド鋼管の厚さの影響を B-2-1 と B $-2-2$ との比較で検討し, 杭内の軸 方向鉄筋の有無の影響を $\mathrm{B}-2-2$ と B-2-3 との比較で検討する。また, 外側に鋼管を取り付け上下端板と溶接したものが B-3 であり, 本論 文ではこれを鋼管巻き中実杭とよぶ。

A-1，A-2 で使用したコンクリートは，膨張材による膨張量が乾燥 収縮による収縮量を上回るように膨張材を混入した設計基準強度 105MPa の SC 杭用の遠心力締固めコンクリートを用いた。A-3 で使用 したコンクリートは, 設計基準強度 $24 \mathrm{MPa}$ の普通コンクリートであ る。B シリーズで使用したコンクリートは, 設計基準強度 40MPa の普 通コンクリートに膨張材を投与し, 膨張材による膨張量が乾燥収縮 による収縮量を上回るように調合設計を行った。

\footnotetext{
1 (国研) 建築研究所構造研究グループ 博士 (工学)

(干 305-0802 茨城県つくば市立原 1)

(一社) コンクリートパイル・ポール協会 修士（工学）

(一社) コンクリートパイル・ポール協会 博士 (工学)
}
Dept. of Structural Engineering, Building Research Institute, Dr. Eng.
Concrete Pile And Pole Industrial Technology Association, M. Eng.
Concrete Pile And Pole Industrial Technology Association, Dr. Eng.


表 1 試験体一覧

\begin{tabular}{|c|c|c|c|c|c|c|c|c|c|c|}
\hline 試験体 & $\begin{array}{c}\text { 外径*1 } \\
(\mathrm{mm})\end{array}$ & $\begin{array}{c}\text { 高ざ*1 } \\
(\mathrm{mm})\end{array}$ & 断面形状 & $\begin{array}{c}\text { コンク } \\
\text { リート厚 } \\
(\mathrm{mm})\end{array}$ & $\begin{array}{c}\text { 鋼管厚 } \\
(\mathrm{mm})\end{array}$ & $\begin{array}{c}\text { 鋼管長 } \\
\text { (mm) }\end{array}$ & $\begin{array}{c}\text { 端板一相城管 } \\
\text { 接続方法 }\end{array}$ & $\begin{array}{l}\text { 空隙幅 } \\
(\mathrm{mm})\end{array}$ & \begin{tabular}{|} 
軸方向 \\
鉄筋
\end{tabular} & $\begin{array}{c}\text { 試験区間 } \\
(\mathrm{mm})\end{array}$ \\
\hline$A-1$ & 400 & 400 & 中空円形 & \begin{tabular}{ll|}
69.3 \\
\end{tabular} & - & - & - & - & - & 368 \\
\hline $\mathrm{A}-2$ & $4 c$ & 400 & 中空円形 & 58.6 & & 348 & 未接続 & 20 & - & 368 \\
\hline$A-3$ & 500 & 500 & 中実正方形 & - & - & - & - & - & 16-D19 & 468 \\
\hline B-1 & 400.8 & 399.5 & 中実円形 & - & - & - & - & - & - & 367.5 \\
\hline$B-2-1$ & 398.1 & 397 & 中実円形 & - & 4.3 & 345 & 未接続 & 20 & - & 365 \\
\hline $\mathrm{B}-2-2$ & 398.4 & 399 & 中実円形 & - & 9.2 & 348 & 未接続 & 20 & - & 367 \\
\hline B-2-3 & 398.8 & 400.6 & 中実円形 & - & 9.2 & 348 & 未接続 & 20 & 16-D32 & 369 \\
\hline B-3 & 399 & 398 & 中実円形 & - & 9.2 & 368 & 溶接 & - & - & 366 \\
\hline
\end{tabular}

表 2 コンクリート＼cjkstart材料試験結果

\begin{tabular}{|c|c|c|c|c|c|c|c|}
\hline 試験体 & $\begin{array}{c}\text { 供試体 } \\
\text { 形状 }\end{array}$ & $\begin{array}{c}\text { 材齢 } \\
(\text { 日 })\end{array}$ & $\begin{array}{c}\text { 縮強度 } \\
\sigma_{\mathrm{B}} \\
(\mathrm{MPa})\end{array}$ & $\begin{array}{c}\text { 圧縮強度 } \\
\text { 時歪 } \\
(\%)\end{array}$ & $\begin{array}{c}\text { ヤング係数 } \\
(\mathrm{GPa})\end{array}$ & $\begin{array}{c}\text { 割裂 } \\
\text { 張強度 } \\
(\mathrm{MPa})\end{array}$ & $\begin{array}{c}\text { ポアソン } \\
\text { 比 }\end{array}$ \\
\hline \hline $\mathrm{A}-1$ & 中空 & 35 & 112.9 & 0.281 & 44.2 & - & 0.214 \\
\hline $\mathrm{A}-2$ & 中空 & 29 & 114.2 & 0.290 & 43.5 & - & 0.211 \\
\hline $\mathrm{A}-3$ & 中実 & 35 & 30.1 & 0.220 & 24.1 & 2.04 & 0.186 \\
\hline $\mathrm{B}-1$ & 中実 & 14 & 42.7 & 0.251 & 30.4 & 3.77 & 0.123 \\
\hline $\mathrm{B}-2-1$ & 中実 & 14 & 50.3 & 0.237 & 31.1 & 3.64 & 0.127 \\
\hline $\mathrm{B}-2-2$ & 中実 & 20 & 38.5 & 0.222 & 28.7 & - & 0.116 \\
\hline $\mathrm{B}-2-3$ & 中実 & 20 & 44.9 & 0.221 & 30.8 & 3.87 & 0.119 \\
\hline $\mathrm{B}-3$ & 中実 & 32 & 41.2 & 0.226 & 29.1 & - & 0.114 \\
\hline
\end{tabular}

表 3 鋼材 材料試験結果

\begin{tabular}{|c|c|c|c|c|c|c|c|}
\hline & 試験体 & $\begin{array}{c}\text { 鋼管厚さ } \\
(\mathrm{mm})\end{array}$ & $\begin{array}{c}\text { ヤング係数 } \\
(\mathrm{MPa})\end{array}$ & \begin{tabular}{|c} 
降伏強度 \\
$(\mathrm{MPa})$
\end{tabular} & \begin{tabular}{|c|} 
降伏歪 \\
$(\%)$
\end{tabular} & $\begin{array}{c}\text { 引張強度 } \\
(\mathrm{MPa})\end{array}$ & $\begin{array}{l}\text { 破断歪 } \\
\text { (\%) }\end{array}$ \\
\hline 鉄筋 D16 & $\mathrm{A}-3$ & - & 205 & 852 & 0.425 & 1051 & 13.4 \\
\hline 鉄筋 D19 & $\mathrm{A}-3$ & - & 188 & 384 & 0.212 & 559 & 17.7 \\
\hline 鉄筋 D32 & B-2-3 & - & 198 & 441 & 0.234 & 610 & 26.5 \\
\hline 鋼管 & B-2-1 & 4.3 & 188 & $359^{* 1}$ & 0.396 & 489 & 32.6 \\
\hline 鋼管 & \begin{tabular}{|c|} 
B-2-2 \\
B-2-3 \\
B-3 \\
\end{tabular} & 9.2 & 208 & 388 & 0.186 & 525 & 24.8 \\
\hline 鋼管 & $A-2$ & 8.7 & 216 & 374 & 0.183 & 539 & 25.9 \\
\hline
\end{tabular}

$\mathrm{A}-1$

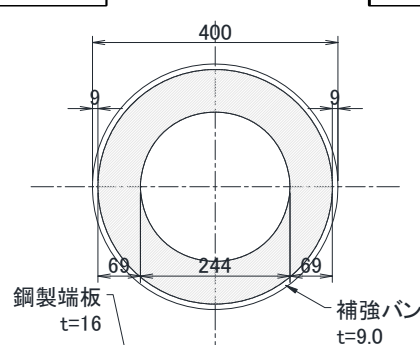

$\mathrm{t}=16$

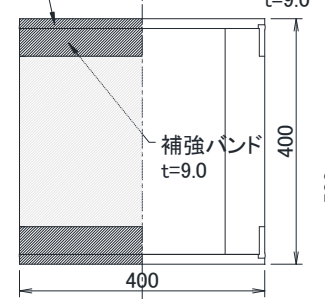

外観図 断面図

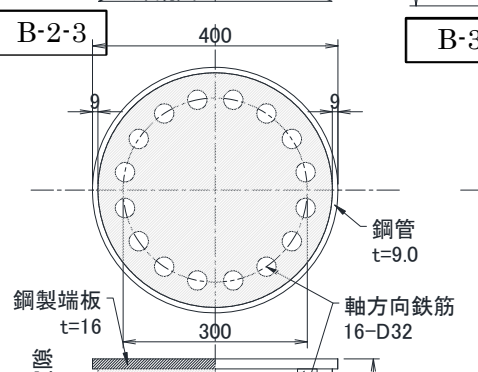

鳟

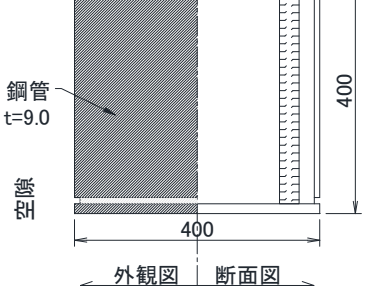

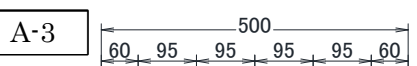

$\begin{array}{lllllll}60 & 95 & 95 & 95 & 95 & 60\end{array}$
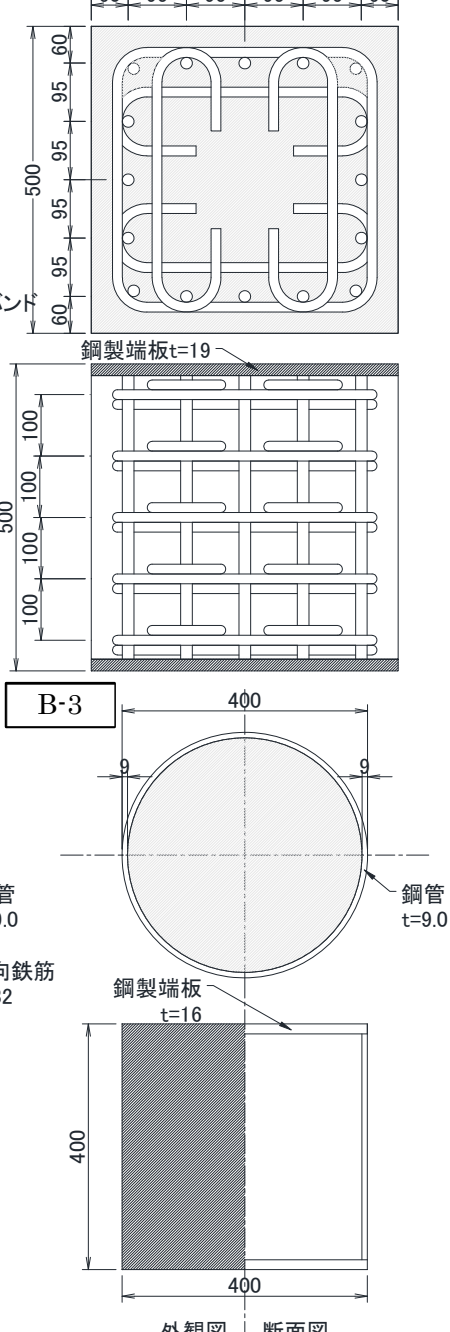

外観図 断面図

\section{2 加力・計測方法}

一軸圧縮実験は，図２に示すような載荷装置を用いて実施した。 鉛直方向に設置した押側最大容量 5MN のジャッキ 4 本を用いて, 試 験体の軸方向に圧縮力を作用させ 1 方向押し切り載荷を行った。載 荷開始時は，試験体に偏心荷重が作用しないように 4 本のジャッキ 荷重が同じになるように制御しながら実験を行った。脆性的に破壊 した A-1, A-2 以外の試験体は，最大荷重の $50 \%$ ～ $80 \%$ の点で変位制 御に切り替えた。変位制御では, 載荷用スタブの 4 隅に取り付けた スタブ変位計（図 3）を用いて，切り替え時からのそれぞれの変位計 の変位増分が同一となるように制御した。試験体の変位は, 図 3 に 示す試験体用変位計 $(\mathrm{D} 1 \sim \mathrm{D} 4)$ を用いて計測した。この試験体用変位 計取り付け時に必要なクリアランスを確保するため, 試験体の上下 に $16 \mathrm{~mm}$ の鋼製端板を設置した。また，試験体外側中央位置に，3 軸 ひずみゲージ（S1〜S4）を貼付した。なお，ひずみゲージと変位計は， 図 3 に示すように 1 ～数字がそれぞれ対応するように同じ方角に 設置した。中空の試験体 (A-1, A-2) は，外側だけでなく内側のコンク リートにも同じ方角に 3 軸ひずみゲージ（SC1〜SC4）を貼付した。ま た，軸方向筋を配した B-2-3 には，鉄筋の軸方向の中央に 1 軸ひず みゲージを同じ方角に貼付した。

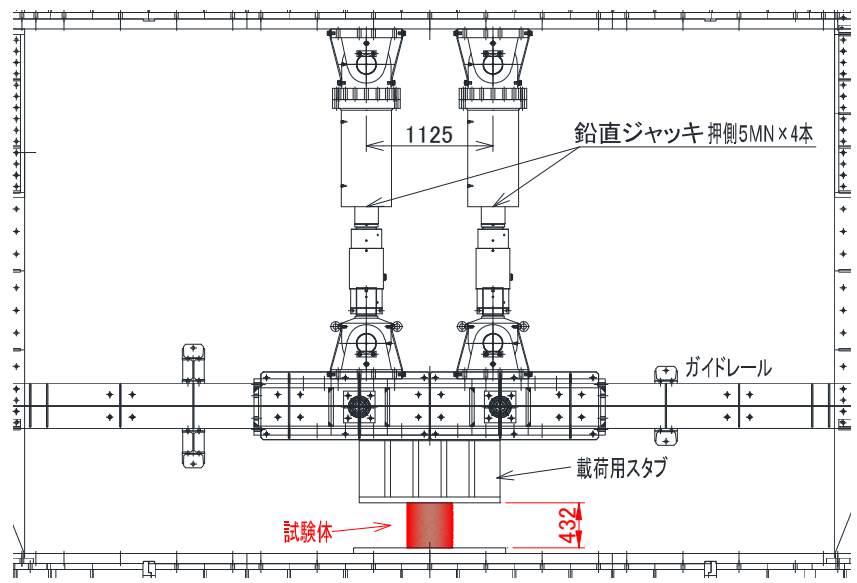

図 2 載荷装置と試験体設置状況
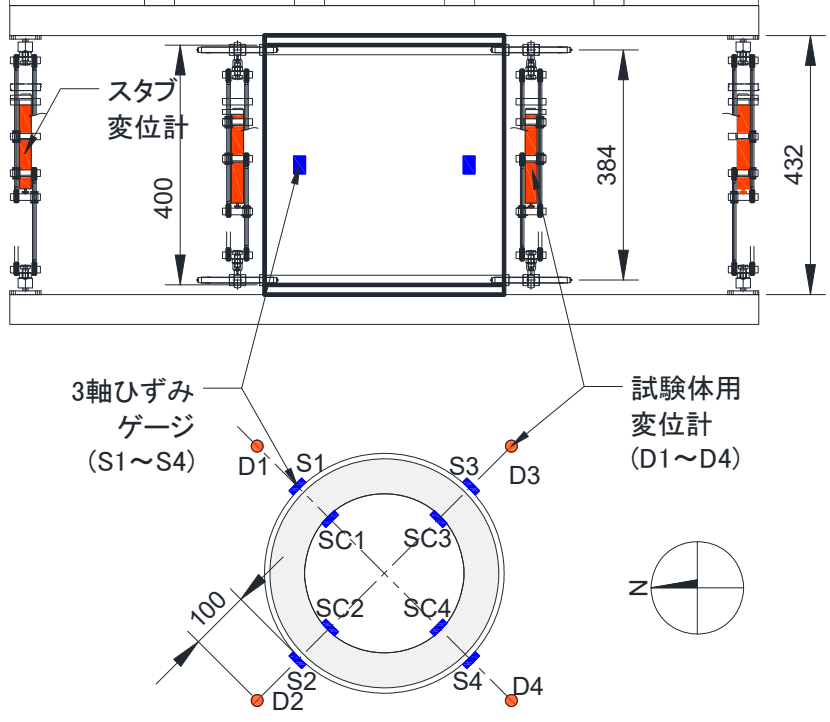

図 3 変位計及びひずみゲージ設置状況（A-2 の例）

図 1 試験体配筋図 


\section{3. 実験結果}

3.1 荷重変形関係と破壊性状（A シリーズ）

図 4 に実験で得られた軸力一軸変位関係を, 図 5 に試験体最終破 壊状況を示す。なお，軸力は 4 本の鉛直ジャッキの圧縮荷重の合計 值を, 軸変位は D1〜D4 の変位計の平均值とした。 $\mathrm{A}-1$ は, 最大耐力 記録後，コンクリートが爆裂し脆性的に破壊した。A-2 は最大耐力記 録後, 荷重が急激に低下し脆性的に破壊した。このとき内部のコンク リートが爆裂し, 試験体上側の空隙 $(10 \mathrm{~mm})$ が閉塞した。その後, 残存 部で軸力 $4000 \mathrm{kN}$ 程度を維持したが, 軸変位 $12 \mathrm{~mm}$ 程度から再び破壊 が進行したため, 載荷を終了した。なお鋼管は載荷終了まで降伏しな かった。A-3 は，軸力 $8000 \mathrm{kN}$ 付近でカバーコンクリートの圧壊が見 られ，その後カバーコンクリートが徐々に剥落し，軸変位 $10 \mathrm{~mm}$ 程度 でせん断補強筋が引張降伏ひずみに達した。その後も徐々に軸力が 上昇し軸変位 $16 \mathrm{~mm}$ 程度で最大耐力を記録した。軸方向鉄筋の座屈と ともに軸力が徐々に低下し，軸変位 $31 \mathrm{~mm}$ 付近で変位計の計測限界に 達したため載荷を終了した。以上のことから, 中空断面である $\mathrm{A}-1,2$ 試験体では A-3 のような圧縮特性は保有できないことを確認した。

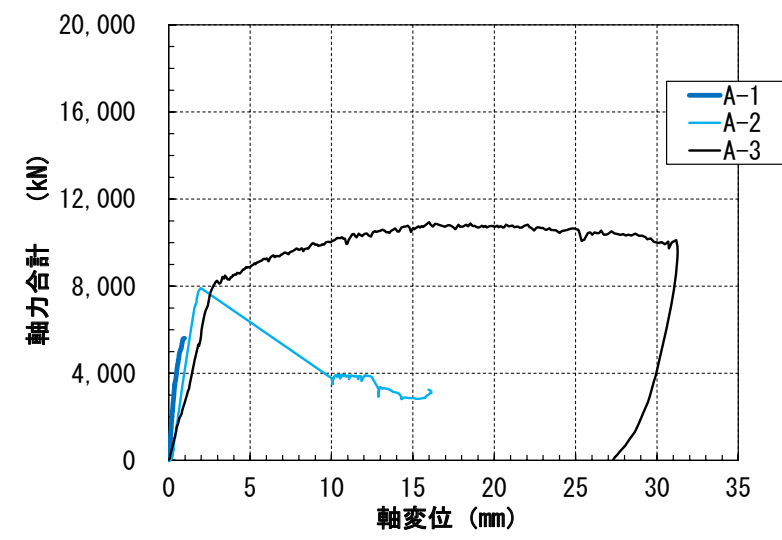

図 4 軸カー軸変位関係（A シリーズ $)$
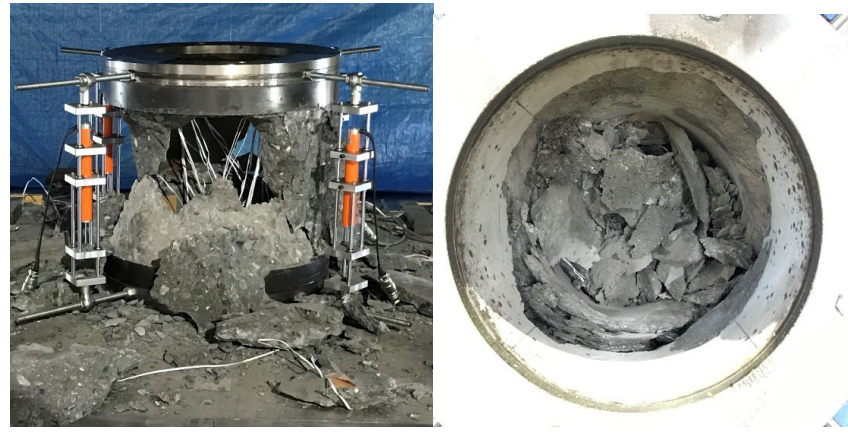

(a) $\mathrm{A}-1$

(b) A-2 (中空部を司見いた写真)

図 5 試験体最終破壊状況（A シリーズ）

\section{2 荷重変形関係と破壊性状（B シリーズ）}

図 6 に実験で得られた軸力一軸変位関係を，図 7 に試験体最終破 壊状況を示す。B-1 は, $7360 \mathrm{kN}$ の最大荷重を記録した後, 荷重が急激 に低下し脆性的に破壊した。アンボンド鋼管巻き中実杭 B-2-1 およ び B-2-2 は，鋼管が円周方向に引張降伏した付近で岡性が変化し荷 重の増加が緩やかになった。その後荷重がほぼ一定となったが，上下 端部に設けた空隙が閉塞したことで，B-2-1 では軸変位 $15 \mathrm{~mm}$ 付近， B-2-2 では軸変位 $20 \mathrm{~mm}$ 付近から荷重が増加した。両試験体とも変位
計の計測限界に達したため載荷を終了した。なお，載荷終了後に B2-1 を確認したところ, 試験体下部の鋼管に軸方向の亀裂及び鋼管の 局部座屈が観察された。これは, 鋼管の空隙が閉塞しさらに圧縮され たことで, 亀裂及び局部座屈が発生したと考えられる。B-2-3 は, 図 6 に示すように載荷初期の軸変位の計測に不備があり立ち上がりの 剛性が正しく計測できていないが，軸力 $6700 \mathrm{kN}$ 時点で軸方向鉄筋の うち 1 本に圧縮降伏がみられ，軸力 $11370 \mathrm{kN}$ 時点でひずみゲージを 貼付した軸方向鉄筋 4 本全てが圧縮降伏した。その後, 荷重が増加 し鋼管が円周方向に引張降伏した付近で剛性が変化し, 荷重の増加 が緩やかになったが, 4 本のうちの 1 本の鉛直ジャッキが定格容量に 達したために最後まで押し切ることができず，載荷を終了した。B-3 は最大耐力を記録した軸変位 $8.6 \mathrm{~mm}$ 付近で鋼管の座屈が見られた。 その後軸力が徐々に低下し, 変位計の計測範囲に達したため載荷を 終了した。

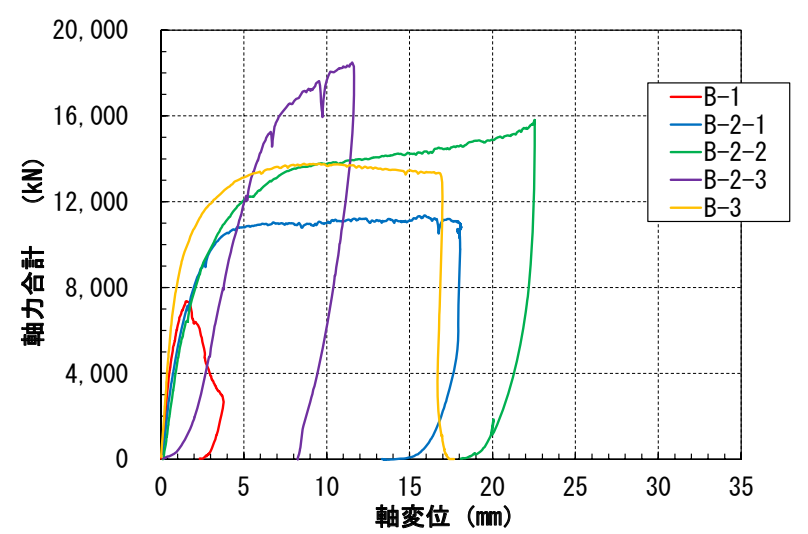

図 6 軸カー軸変位関係（B シリーズ）

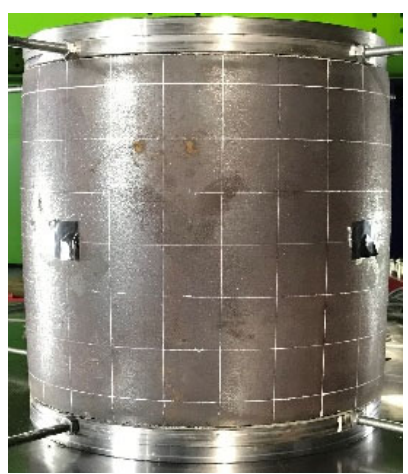

(a) $\mathrm{B}-2-2$

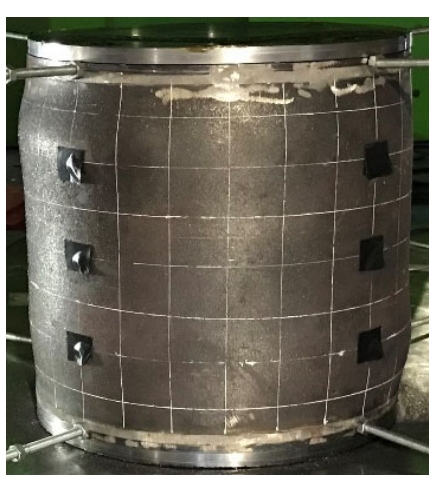

(b) $B-3$
図 7 試験体最終破壊状況（B シリーズ）

\section{3 実験データの整理}

本実験で得られたデータについて, 各試験体間の比較や試験体の 構造性能を評価するために，下記のように実験結果の整理を行った。 載荷開始から終局軸ひずみに達するまでの $\sigma_{\mathrm{c}} / \sigma_{\mathrm{B}}$ 一軸ひずみ関係を 図 8 に, 各試験体の最大耐力時, 鋼管降伏時および終局時の $\sigma_{c} / \sigma_{\mathrm{B}}$ お よび軸ひずみを表 4 に示す。

\section{（1）軸ひずみ及び軸応力}

軸ひずみは, 計測した軸変位を試験区間 (試験体のコンクリート部 分の高さで, 表 1 参照) で除して算定した。また, 試験体に作用した 軸力のうち, 鋼管や軸方向鉄筋の負担軸力（3.3 節 (4) 参照）を引い 
てコンクリート部のみの負担軸力を算出し，それをコンクリートの 断面積で除して，コンクリート応力 $\sigma_{\mathrm{c}}$ を計算する。この $\sigma_{\mathrm{c}}$ を材料試 験のコンクリート圧縮強度 $\sigma_{\mathrm{B}}$ で除した值を検討に用いる。

\section{(2) B-2-3 の補正}

B-2-3 は, 計測に不備があり初期の軸変位が正しく計測できていな い。そこで，剛性が一定になった軸力 $4000 \mathrm{kN}$ 時と鉄筋降伏直前の軸 力 $6700 \mathrm{kN}$ 時の計測点を結んだ傾きを初期剛性と見なし，載荷開始か ら軸力 $4000 \mathrm{kN}$ までの間はこの傾きで線形挙動すると仮定した。図 8 においては，B-2-3 はその仮定に基づき軸ひずみの修正を行った。

\section{（3）終局軸ひずみおよび最大耐力}

A-1, A-2, B-1 のように脆性的に破壊した試験体の終局軸ひずみは, 最大耐力時の軸ひずみとする。 $\mathrm{B}-2-1, \mathrm{~B}-2-2$ のように，アンボンド 鋼管の上下端部に設けた空隙が閉塞した場合は，その閉塞した点を 終局軸ひずみとする。A-3, B-2-3, B-3 では, 載荷終了まで軸力が最 大耐力の $80 \%$ 以下に低下しなかったため，計測できた最大軸ひずみ を終局軸ひずみとする。また, 最大耐力は載荷開始から終局ひずみに 達するまでの間に記録した最大の軸力とする。

\section{（4）鋼管の降伏判定，および，鋼管，軸方向鉄筋の負担力}

鋼管の降伏の判定は，鋼管に貼付した 3 軸ひずみゲージの計測値 のロゼット解析 (ポアソン比 0.3 とした) により行った。ロゼット解 析による主応力を用いて，(1)式のミーゼスの降伏条件により鋼管の 降伏を判定した。なお，4 方向に貼付した 3 軸ひずみゲージのうち， 一つでも降伏条件を満たした点を鋼管の降伏点とみなした。軸力に 対する鋼管の負担力は，(2)式による材軸方向の応力 $\sigma_{\mathrm{sa}}$ に鋼材の断 面積を乗じて計算した。軸方向鉄筋の負担力は貼付した 1 軸ひずみ ゲージの計測值から計算した。なお，鋼管および軸方向鉄筋の負担応 力は, 降伏後は増えずに一定として計算を行った。鋼管降伏後は, 鋼 管の周方向の応力が強制変形により増加しそれに伴い軸方向の応力 は減少する可能性があるが，鋼管の負担応力を多く評価することは コンクリートの軸方向応力を少なく評価することになるため，拘束 されたコンクリートの評価にとっては安全側の仮定である。

$\sigma_{s m}=\sqrt{\sigma_{\min }^{2}-\sigma_{\min } \sigma_{\max }+\sigma_{\max }^{2}} \geq \sigma_{y}$

$\sigma_{s a}=\frac{\sigma_{\min }+\sigma_{\max }}{2}+\frac{\sigma_{\min }-\sigma_{\max }}{2} \cos 2 \theta$

ここで $\sigma_{s m}$ : ミーゼスの相当応力 $(\mathrm{MPa})$

$\sigma_{\max }, \sigma_{\min }$ : 最大主応力, 最小主応力 $(\mathrm{MPa})$

$\sigma_{\mathrm{y}}:$ 鋼材降伏強度 $(\mathrm{MPa})$

$\sigma_{\mathrm{sa}}:$ 軸方向応力 $(\mathrm{MPa})$

$\theta:$ 試験体周方向に対寸る主応力方向の角度（rad）

表 4 実験結果一覧

\begin{tabular}{|c|c|c|c|c|c|c|c|c|c|c|}
\hline \multirow[b]{2}{*}{ 試験体 } & \multicolumn{5}{|c|}{ 最大耐力時 $* 1$} & \multicolumn{4}{|c|}{ 鋼管降伏時 $* 2$} & \multirow{2}{*}{$\begin{array}{c}\text { 終局 } \\
\text { 軸ひ } \\
\text { ずみ } \\
(\%)\end{array}$} \\
\hline & $\begin{array}{l}\text { 軸力 } \\
(\mathrm{kN}) \\
\end{array}$ & \begin{tabular}{|c|}
$\begin{array}{c}\text { 軸ひずみ } \\
(\%)\end{array}$ \\
\end{tabular} & $\begin{array}{l}\max \sigma_{\mathrm{c}} \\
(\mathrm{MPa}) \\
\end{array}$ & $\begin{array}{r}\max \sigma_{\mathrm{c}} \\
/ \sigma_{\mathrm{B}}\end{array}$ & $\begin{array}{l}\sigma_{\text {sa }} \\
/ \sigma_{y}\end{array}$ & $\begin{array}{l}\text { 軸力 } \\
(\mathrm{kN})\end{array}$ & $\begin{array}{c}\begin{array}{c}\text { 軸ひずみ } \\
(\%)\end{array} \\
\end{array}$ & $\begin{array}{r}\mathrm{y} \sigma_{\mathrm{c}} \\
(\mathrm{MPa}) \\
\end{array}$ & $\begin{array}{l}{ }_{\mathrm{y}} \sigma_{\mathrm{c}} \\
/ \sigma_{\mathrm{B}}\end{array}$ & \\
\hline$A-1$ & 5614 & \begin{tabular}{|l|}
0.263 \\
\end{tabular} & 78.0 & 0.69 & & & & 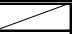 & & 0.263 \\
\hline$A-2$ & 7914 & 0.533 & 132.7 & 1.16 & 0.00 & & 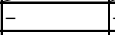 & - & - & 0.533 \\
\hline$A-3$ & 10943 & 3. 42 & 44.6 & 1.48 & 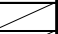 & 10211 & 2.21 & 41.6 & 1.38 & 6.66 \\
\hline $\mathrm{B}-1$ & & 0.427 & 3 & 1.37 & $>$ & 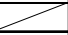 & & 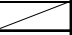 & 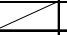 & 0.427 \\
\hline B-2-1 & 227 & 3. 28 & 91.8 & 1.82 & 0.15 & 10494 & 1.06 & 85.7 & 1.70 & 4.14 \\
\hline$B-2-2$ & 14898 & 5.44 & 122.9 & 3.20 & 0.22 & 9901 & 0.833 & 79.7 & 2.07 & 5.4 \\
\hline$B-2-3$ & 18483 & 2. 68 & 114.1 & 2.54 & 0.31 & 15227 & 1.35 & 83.9 & 1.87 & 2.71 \\
\hline B-3 & 13774 & 2.36 & 84.6 & 2.05 & 0.95 & 5235 & 0.138 & 19.7 & 0.48 & 4. 61 \\
\hline
\end{tabular}

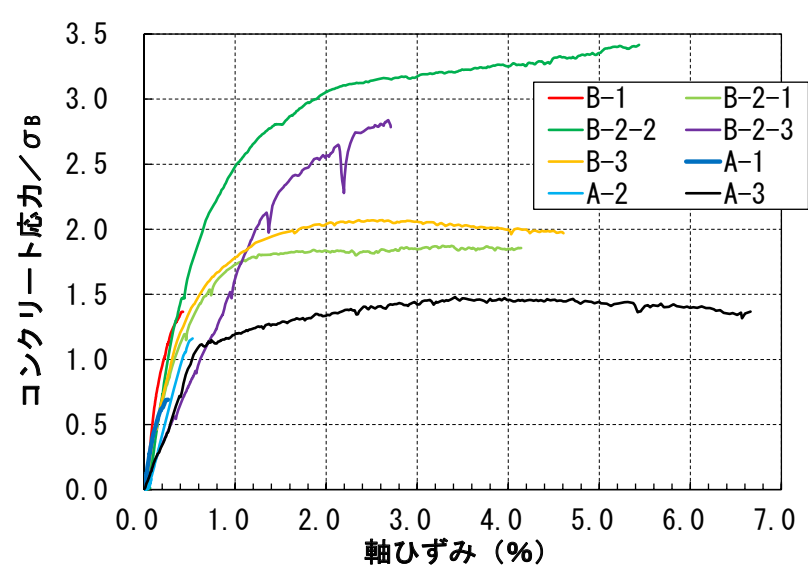

図 $8 \sigma_{\mathrm{c}} / \sigma_{\mathrm{B}}$ 一軸ひずみ関係

\section{4. 実験結果の検証}

\section{1 A シリーズの比較}

表 4 に示すように, $\mathrm{A}-1, \mathrm{~A}-2$ の最大耐力時の ${ }_{\text {max }} \sigma_{\mathrm{c}} / \sigma_{\mathrm{B}}$ はそれぞれ 0.69 と 1.16 であり, A-2 は 1.0 を超えた。一方で, A-1 の ${ }_{\max } \sigma_{\mathrm{c}} / \sigma_{\mathrm{B}}$ は 1.0 を下回っており，この原因を試験体コンクリートに貼付した ロゼット解析と，モール・クーロンの破壊基準を用いて検討する。A1, A-2 において, 最大耐力直前の計測值を用いたロゼット解析によ り得られたコンクリートの応力状態を図 9, 図 10 にそれぞれ示す。 また式(3)のように, クーロン破壊線を示す。なお，各係数は文献 7) と同様の值を用いた。

$\tau=c+\sigma \tan \phi$

ここで $\sigma, \tau$ : 垂直応力, せん断応力 $(\mathrm{MPa})$

$c$ : 粘着力 $(\mathrm{MPa})\left(=0.25 \sigma_{\mathrm{B}}\right)^{8)}$

$\phi$ : 内部摩擦角 $(\mathrm{rad}) \quad(\tan \phi=0.75)^{8)}$

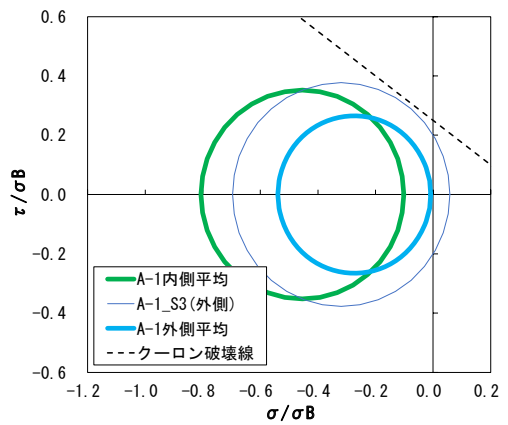

図 9 最大耐力直前のコンクリートの応力状態 $(A-1)$

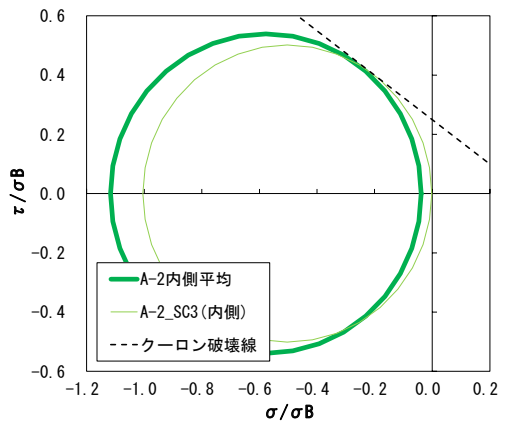

図 10 最大耐力直前のコンクリートの応力状態 $(A-2)$ 
図 9 を見ると, 試験体の内側と外側のそれぞれの平均值ではクー ロンの破壊線に接していないが，外側の 3 軸ゲージの内最もひずみ が大きかった S3 ゲージのモールの応力円はクーロン破壊線と近接し ている。このことから，A-1 は設置時の試験体の偏りにより，ある方 向に偏って変形したために, ${ }_{\max } \sigma_{\mathrm{c}} / \sigma_{\mathrm{B}}$ が 1.0 を下回ったと推測できる。 一方 A-2 では, 図 10 に示すように試験体の内側の平均值及び最もひ ずみが大きかった SC3 ゲージの両方がクーロン破壊線に接しており， かつほぼ同じような応力状態となっており, 設置時の試験体の偏り が少なかったことがわかる。

表 4 に示すように，A-1，A-2 の終局軸ひずみは 0.263\%，0.533\% である。圧縮勒性比較用の A-3 の $6.66 \%$ と比べると， $1 / 10$ 以下とな った。A-1，A-2 の破壊性状も脆性破壊していることから，中空試験 体では圧縮勒性のある杭の開発は難しいことがわかった。

\section{2 アンボンド鋼管巻き中実杭の構造性能}

表 4 に示すように, アンボンド鋼管巻き中実杭試験体（B-2 シリー ズ） 3 体の ${ }_{\max } \sigma_{\mathrm{c}} / \sigma_{\mathrm{B}}$ はそれぞれ $1.82 ， 3.20,2.54$ であり, B-1の 1.37 と比べると, アンボンド鋼管巻き中実杭とすることで拘束効果によ り強度が上昇することがわかった。また，アンボンド鋼管の厚さを 4. $3 \mathrm{~mm}(\mathrm{~B}-2-1)$ から $9.2 \mathrm{~mm}(\mathrm{~B}-2-2)$ に厚くすることで ${ }_{\max } \sigma_{\mathrm{c}} / \sigma_{\mathrm{B}}$ が 1.82 から 3.20 に上昇しており, アンボンド鋼管の厚さを厚くすることで さらに拘束効果が上昇することがわかった。なお,この鋼管の厚さは, 径厚比（直径を鋼管厚さで除した值）で 93.0 (B-2-1）と 43.5 (B-22) である。大地震時に対する設計が行われた実際の建物における統 計調查を行った文献 8) によると SC 杭の径厚比の平均値は 70 である ことを考慮すると, 平均よりも径厚比を下げることで十分な拘束効 果が得られることがわかる。一方で，B-2-2 に軸方向鉄筋を入れると ${ }_{\max } \sigma_{\mathrm{c}} / \sigma_{\mathrm{B}}$ が 3.20 から 2.54 と減少した。これは載荷装置の限界により B-2-3の真の最大耐力が計測できなかったためである。

ここで，鋼管降伏時の内部コンクリートの応力状態について検討 する。表 4 より, B-2 シリーズ 3 体の鋼管降伏時の ${ }_{\mathrm{y}} \sigma_{\mathrm{c}} / \sigma_{\mathrm{B}}$ は, 1.70 〜2. 07 倍強度が上昇している。一方で, 軸ひずみは $0.833 \%$ ～ $1.35 \%$ と なり, 材料試験結果（表 2）の圧縮強度時ひずみ $0.221 \%$ ～ $0.237 \%$ と比 べると 4 倍以上の軸ひずみとなった。このことから，鋼管降伏時に おいて, 拘束効果による強度上昇よりもひずみの上昇が大きくなり, 強度とひずみが同じように上昇するわけではないことがわかった。

また, 鋼管降伏時の ${ }_{\mathrm{y}} \sigma_{\mathrm{c}} / \sigma_{\mathrm{B}}$ に対して, 最大耐力時の ${ }_{\text {max }} \sigma_{\mathrm{c}} / \sigma_{\mathrm{B}}$ の耐力 上昇率について検討する。表 4 に示すように，B-2-1 では 1. 07 (=1.82/1. 70) 倍耐力が上昇したが, B-2-2では 1.54(=3.20/2.07) 倍耐力が上昇しており，鋼管厚を厚くすることで降伏時からの耐力 上昇率が大きくなることがわかった。

表 4 に示すように, アンボンド鋼管巻き中実杭試験体（B-2 シリー ズ） 3 体の終局軸ひずみはそれぞれ，4.14\%, 5.44\%, 2.71\%となり， 圧縮勒性の比較用の試験体 A-3 の $6.66 \%$ と比べると, 小さいものの B-2-1，B-2-2 は 4\%を超えており十分な勒性能を有することがわかっ た。 B-2-1，B-2-2 は試験体上下端部に設けた空隙が閉塞することで 終局軸ひずみが決定しているので, この空隙を適切に設定すること で圧縮勒性のさらなる向上が期待できる。

\section{3 鋼管巻き中実杭の構造性能}

表 4 に示すように, B-3 の ${ }_{\max } \sigma_{\mathrm{c}} / \sigma_{\mathrm{B}}$ は 2.05 であり, B-1の 1.37 と 比べると拘束効果があることがわかった。また, 終局軸ひずみも
4. $61 \%$ と $4 \%$ 超えており十分な勒性能を有することがわかった。

\section{4 鋼管とコンクリートとの固着性状}

B-2-2 は，B-3 と鋼管厚が同一だが端部に空隙を設けた試験体であ る。表 4 に示すように, B-2-2 の ${ }_{\max } \sigma_{\mathrm{c}} / \sigma_{\mathrm{B}}$ は 3.20 であり, B-3 の 2.05 と比べると拘束効果が高いことがわかった。図 11 に各試験体の鋼管 の応力状態を示す。図 11 では, 鋼管に貼付した 3 軸ひずみゲージの ロゼット解析により, 実験開始時から降伏時までの各試験体の主応 力の経過を示した。また, 試験体ごとに比較するため, 主応力を降伏 強度 $\sigma_{\mathrm{y}}$ で除して無次元化した。これを見ると，B-3 は最大主応力が ほぼ 0 のまま最小主応力のみが増加して降伏に至っており，周方向 にはほとんど引張応力が作用していないことがわかる。このことか ら, B-3 では少なくとも鋼管が降伏するまではコンクリートと鋼管が 一体となって挙動していることがわかった。一方で, B-2-2 は最小主 応力の值が観測されているものの, 基本的には最大主応力が卓越し ており，周方向に大きな引張応力が作用していることがわかる。端部 に空隙を設けることで, B-3 と異なり鋼管とコンクリートが別々に挙 動していることがわかる。

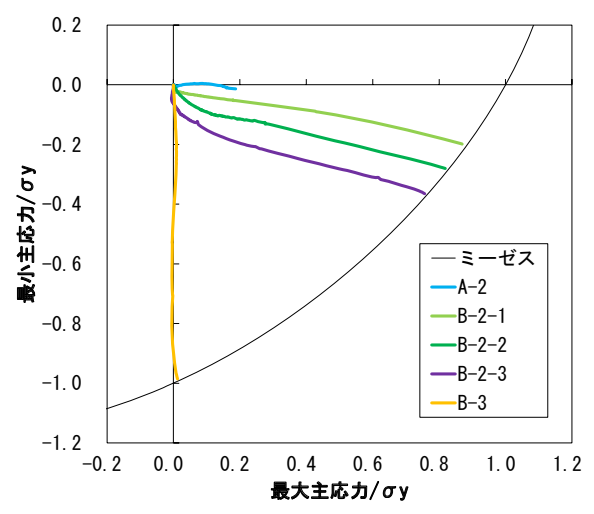

図 11 鋼管の応力状態

表 4 に示すように, 試験体最大耐力時の材軸方向の応力 $\sigma_{\mathrm{sa}}$ を鋼管 の降伏強度 $\sigma_{\mathrm{y}}$ で除した值は, A-2 では 0.00 であり鋼管とコンクリー トの付着はないと言ってよい。一方, アンボンド鋼管巻き中実杭試験 体（B-2 シリーズ） 3 体の $\sigma_{\mathrm{sa}} / \sigma_{\mathrm{y}}$ はそれぞれ $0.15 ， 0.22 ， 0.31$ であ り, 試験体の最大耐力が大きくなるにつれて大きくなった。しかし, 降伏強度と比べると小さい範囲であり, 鋼管とコンクリートの間の 付着を除去するような特別な処理を施さなくても, 端部に空隙を設 けることで付着がきれることがわかった。

\section{5. 耐力評価}

A-2， B-2 シリーズ， B-3 の 5 つの試験体の最大耐力を既往の評価 法を用いて検討する。基本となる耐力評価式は，式(4)に示すような 円形断面を持つ CFT 短柱の軸圧縮耐力式 ${ }^{9)}$ に軸方向鉄筋の第 3 項を 累加した式を用いて計算する。ただし, 試験体の形状により式(4)で 用いる各係数が異なる。

$$
\begin{aligned}
& { }_{c a l} P={ }_{c a l} \sigma_{c} \cdot A_{c}+{ }_{c a l} \sigma_{s} \cdot A_{s}+{ }_{r} \sigma_{y} \cdot A_{r} \\
& \text { ここで } \quad{ }_{c a l} \sigma_{c}={ }_{r} \gamma_{U} \cdot \sigma_{B}+k \cdot \sigma_{r} \\
& \sigma_{r}=\alpha \cdot \frac{2 t}{D-2 t} \sigma_{y} \quad{ }_{c a l} \sigma_{s}=\beta \sigma_{y}
\end{aligned}
$$


${ }_{c a l} P$ : 試験体軸圧縮耐力 $(\mathrm{N})$

${ }_{c a l} \sigma_{c}$ : 拘束されたコンクリート部の計算圧縮強度 $(\mathrm{MPa})$

${ }^{c a l} \sigma_{s}:$ 鋼管部の計算圧縮強度 $(\mathrm{MPa})$

$r \sigma_{y}:$ 軸方向鉄筋の降伏強度 $(\mathrm{MPa})$

$A_{c}, A_{s}, A_{r}$ : コンクリート, 鋼管, 鉄筋の断面積 $\left(\mathrm{mm}^{2}\right)$ ${ }_{c} \gamma_{U}$ : コンクリートの強度低減係数 $k$ : 拘束係数

$\sigma_{\mathrm{r}}:$ 拘束コンクリートに作用する側圧 $(\mathrm{MPa})$

$D, t:$ 試験体直径，鋼管厚さ $(\mathrm{mm})$

$\alpha, \beta$ : 周方向応力成分比, 軸方向応力成分比

\section{1 A-2 の耐力評価}

A-2 は，アンボンド鋼管を中空円形杭に巻いた試験体なので，文献 6)の耐力式を適用する。文献 6) では式 (4) の係数について, $c \gamma_{U}=1.0$, $\alpha=1.0, \beta=0$, 及び $k$ については式(5)を用いた評価式が提案されてい る。文献 6) による計算式の推定精度は，適用範囲の試験体に対して 実験值／計算值が $1.01 \sim 1.11$ の範囲であった。なお, 式(5)の適用範 囲空洞率 5\%〜25\%に対して，A-2 の空洞率は 44. 0\%のため適用範囲 外である。計算值 ${ }_{c a l} P_{1}$ を表 5 に示す。表 5 に示寸ように, exp $P /{ }_{c a l} P_{1}$ が 0.95 であり実験值が計算值を下回った。これは, A-2 ではアンボンド 鋼管が降伏する前にコンクリートの爆裂により最大耐力が決まって いることから，アンボンド鋼管の拘束効果が十分に発揮されなかっ たことが原因と考えられる。

$k=5.17-\frac{H R a}{12}$

ここで HRa: 空洞率 $(\%) \quad\left(=A_{H} /\left(\pi D^{2} / 4\right) \times 100\right)$

$A_{H}:$ 空洞部の面積 $\left(\mathrm{mm}^{2}\right)$

\section{2 アンボンド鋼管巻き中実杭試験体の耐力評価}

アンボンド鋼管巻き中実杭試験体 (B-2 シリーズ) では, 文献 7)の 耐力式を適用する。文献 7) では式(4)の係数について, ${ }_{c} \gamma_{U}=1.0, \alpha=1.0$, $\beta=0, k=4.0$ を用いた評価式が提案されている。計算值 ${ }_{c a l} P_{1}$ を表 5 に 示す。表 5 に示すように, B-2-1, B-2-2 において exp $P$ / cal $P$ が 1.15 お よび 1.16 であり実験值を安全側に評価できた。最大耐力が計測でき なかった B-2-3 については参考值であるが， ${ }_{\text {exp } P /}{ }_{\text {cal }} P 1$ が 1.04 と 1 を 上回った。

\section{3 鋼管巻き中実杭試験体の耐力評価}

鋼管巻き中実杭試験体 B-3 では, 文献 10)の耐力式を適用する。文 献 10)では式(4)の係数について, $\alpha=0.19, \beta=0.89, k=4.1$ 及び ${ }_{c} \gamma_{U}$ に ついては式(6)を用いた評価式が提案されている。計算值 ${ }_{c a l} P_{1}$ を表 5 に示す。表 5 に示すように, ${ }_{\text {exp }} P /{ }_{c a l} P_{1}$ が 1.44 であり実験值を安全側 に評価できた。

${ }_{c} r_{U}=1.67 D^{-0.112}$

表 5 耐力計算結果一覧

\begin{tabular}{|c|c|c|c|c|c|c|c|}
\hline 試験体 & $\begin{array}{c}\text { 最大耐力 } \\
\exp \mathrm{P} \\
(\mathrm{kN})\end{array}$ & $c \gamma_{u}$ & $\alpha$ & $\beta$ & k & $\begin{array}{l}\text { cal } P_{1} \\
(\mathrm{kN})\end{array}$ & $\begin{array}{l}\exp P \\
/_{\text {cal }} P_{1}\end{array}$ \\
\hline$A-2$ & 7914 & 1.00 & 1.00 & 0.00 & 1.50 & 8335 & 0.95 \\
\hline B-2-1 & 11227 & 1.00 & 1.00 & 0.00 & 4.00 & 9776 & 1.15 \\
\hline B-2-2 & 14898 & 1.00 & 1.00 & 0.00 & 4.00 & 12886 & 1.16 \\
\hline B- $2-3^{* 1}$ & 18483 & 1.00 & 1.00 & 0.00 & 4.00 & 17725 & 1.04 \\
\hline B-3 & 13774 & 0.85 & 0.19 & 0.89 & 4.10 & 9558 & 1.44 \\
\hline
\end{tabular}

\section{6. まとめ}

圧縮勒性のあるコンクリート杭の開発を目的として, 8 体の試験体 を製作し一軸圧縮実験を行った結果，以下の知見を得た。

(1) 中空断面既製コンクリート杭は，外側にアンボンド鋼管を取り付 けても脆性的に破壊し，必要な圧縮勒性が得られない。

(2)今回のように，付着を除去するような処理を特別施していないア ンボンド鋼管巻き中実杭について, 外側に取り付けたアンボンド 鋼管による拘束効果により, 一軸圧縮強度の上昇 (1.82 3.20 倍) と圧縮勒性能の向上を確認できた。このときアンボンド鋼管の厚 さを厚くすることでさらに拘束効果が上昇することがわかった。

(3) 鋼管巻き中実杭は, 外側に取り付けた鋼管による拘束効果により 一軸圧縮強度の上昇および終局ひずみ $4 \%$ を超える勒性能の向上 が確認できた。

(4)鋼管巻き中実杭及びアンボンド鋼管巻き中実杭について, 既往の 評価式を用いて最大耐力を評価したところ，安全側に評価できた。

\section{謝辞}

本研究は，(国研）建築研究所指定課題「既存鉄筋コンクリート造建 築物の地震後継続使用のための耐震性評価手法の開発」により実施 しました。関係各位に謝意を表します。

\section{参考文献}

1) 金子治，中井正一，阿部秋男，向井智久：東北地方太平洋沖地震における杭 基礎被害の要因分析に向けた検討 その 3 杭基礎の強度・変形特性に関する 実験, 日本建築学会大会学術講演梗概集, 2014.9, pp. 699-700

2) 渡邊秀和ほか 4 名：2016 年熊本地震により被災した RC 造庁舎における基 礎構造部材の損傷調査, 第 15 回日本地震工学シンポジウム, pp. $1844^{\sim} 1853$, 2018. 12

3) 喜々津仁密ほか 7 名 : 地震後の継続使用性を確保した新築建築物の設計・耐 震性能評価 その 1〜その 6, 日本建築学会学術講演梗概集, pp. 45-56, 2015.9 4) 草刈崇圭ほか 5 名 : 地震後の継続使用性を確保した新築建築物の設計・耐震 性能評価 その 7 その 11, 日本建築学会学術講演梗概集, pp. 43-52, 2016.8

5）向井智久ほか 16 名: 大地震後の継続使用性を確保するためのコンクリート 系杭基礎構造システムの構造性能評価に関寸る研究, 建築研究資料第 195 号, 2019. 10

6) Miyaki, S., et al. : Evaluation formula of compressive strength of centrifugal concrete filled steel circular tubular columns using super high strength concrete, AIJ J. Struct. and Constr. Eng., No. 482, pp. 151-160, 1996.4 (in Japanese)

宮木聡ほか 5 名 : 遠心成形コンクリート充填円形鋼管柱の軸圧縮而力式，日 本建築学会構造系論文集，No. 482，pp. 151-160， 1996.4

7) Sato, T. : Confining mechanism and analytical model in circular concrete-filled steel tube under axial force, AIJ J. Struct. and Constr. Eng., No. 452, pp. 149-158, 1993.10 (in Japanese)

佐藤孝典: 円形断面の充填鋼管コンクリート構造におけるコンファインド効 果のメカニズムとそのモデル化, 日本建築学会構造系論文集, No. 452, pp. 149-158, 1993. 10

8) Kaneko, 0. : Surveys on actual applicable conditions of concrete pile foundations for seismic design against severe earthquakes, AIJ J. Technol. Des., Vol. 23, No. 53, pp. 87-92, 2017. 2 (in Japanese) 金子治: 大地震に対する耐震設計におけるコンクリート杭の適用条件に関す る実態調査, 日本建築学会技術報告集, Vol. 23, No. 53, pp. 87-92, 2017.

9）日本建築学会：コンクリート充填鋼管構造設計指針，2008.10

10) 崎野健治ほか 3 名：コンクリート充填円形鋼管短柱の中心圧縮而力, 構造 工学論文集, Vol. 48B, pp. 231-236, 2002.3

[2020 年 10 月 6 日原稿受理 2020 年 11 月 24 日採用決定］ 